\title{
STUDI RADIOSENSITIVITAS DAN ANALISIS KERAGAMAN M1 KACANG TUNGGAK (Vigna unguiculata L) HASIL INDUKSI MUTASI
}

\author{
Yukarie Ayu Wulandari ${ }^{1}$, Sobir $^{2 *}$ dan Syarifah Iis Aisyah ${ }^{2}$ \\ ${ }^{1}$ Mahasiswa Program Magister Pemuliaan dan Bioteknologi Tanaman pada Sekolah \\ Pascasarjana Institut Pertanian Bogor \\ ${ }^{2}$ Departemen Agronomi dan Hortikultura Fakultas Pertanian Institut Pertanian Bogor \\ Jl. Meranti Babakan Dramaga Bogor 16680 \\ *Email : rsobir@yahoo.com
}

\begin{abstract}
ABSTRAK
Kacang tunggak sebagai salah satu kacang indigenous potensi untuk substitusi kedelai sebagai bahan dasar pembuatan tempe dan tahu. Sumber daya genetik kacang tunggak perlu ditingkatkan keragamannya sebagai sumber plasma nutfah untuk perakitan varietas unggul baru. Induksi mutasi iradiasi sinar gamma pada kacang tunggak diharapkan dapat meningkatkan keragaman. Penelitian dilaksanakan dengan iradiasi biji kacang tunggak genotipe KM-4 dengan dosis 0, 200, 400, 600 dan 800 Gy dan dianalisis untuk memperoleh $\mathrm{LD}_{50}$ dan dilakukan iradiasi kembali dengan dosis $0, \mathrm{LD}_{50-100}, \mathrm{LD}_{50-50}, \mathrm{LD}_{50}, \mathrm{LD}_{50+50}$ dan $\mathrm{LD}_{50+100}$ Gy. Karakter yang diamati meliputi tinggi tanaman, lebar tajuk, panjang tangkai, panjang daun, lebar daaun, periode panen, panjang polong, jumlah biji/polong, berat biji/tanaman dan kandungan protein biji kacang tunggak. Hasil penelitian menunjukkan bahwa nilai $\mathrm{LD}_{50}$ tanaman kacang tunggak adalah $724,84 \mathrm{~Gy}$, iradiasi sinar gamma pada dosis 750 Gy menghasilkan keragaman tertinggi dan iradiasi sinar gamma tidak meningkatkan keragaman terhadap kandungan protein biji kacang tunggak.
\end{abstract}

Kata kunci: Gy, iradiasi, $\mathrm{LD}_{50}$ dan sinar gamma

\section{ABSTRACT}

Cowpea as one of the indigenous beans has the potential to substitute soybeans as a basic ingredient in making tempeh and tofu. The genetic resources of cowpea need to be increased in diversity as a germplasm source for assembling new superior varieties. Induction of gamma ray irradiation on cowpea is expected to increase diversity. The study was carried out by irradiation of KM-4 genotype beans with doses of 0, 200, 400, 600 and $800 \mathrm{~Gy}$ and analyzed to obtain $L D_{50}$ and re-irradiation at a dose of $0, L D_{50-100}, L D_{50-50}$, $L D_{50}, L D_{50}+50$ and $L D_{50}+100 G y$. The characters observed included plant height, crown width, stem length, leaf length, leaf width, harvest period, pod length, number of seeds/pods, seed/plant weight and protein content of cowpea seeds. The results showed that the $L D_{50}$ value of cowpea plants was $724.84 \mathrm{~Gy}$, gamma ray irradiation at a dose of 750 Gy produced the highest diversity and gamma ray irradiation did not increase diversity in the protein content of cowpea seeds.

Keywords: gamma ray, Gy, irradiation and $L D_{50}$ 


\section{PENDAHULUAN}

Kacang tunggak sebagai salah satu kacang indigenous potensi untuk substitusi kedelai sebagai bahan dasar pembuatan tempe dan tahu. Potensi hasil biji kacang tunggak cukup tinggi yaitu dapat mencapai 2,0 ton.ha ${ }^{-1}$ (Adiarwanto et al., 1998). Kacang tunggak toleran kekeringan dan toleran terhadap kemasaman tanah sehingga potensial dikembangkan pada lahan kering dalam upaya peningkatan produktivitas lahan (Trustinah et al., 2008). Kacang tunggak memiliki kadar lemak yang lebih rendah sehingga dapat meminimalisasi efek negatif dari penggunaan produk pangan berlemak. Kacang tunggak juga memiliki kandungan vitamin B1 lebih tinggi dibandingkan kacang hijau. Asam amino yang penting dari protein kacang tunggak adalah kandungan asam amino lisin, asam aspartat dan glutamat (Chavan et al., (1989) dikutip (Syarifah 2002). Kandungan protein kacang tunggak mencapai $25,53 \%$ akan tetapi masih lebih rendah dari kandungan protein kedelai yang mencapai 34,9 g (BKPPP, 2014). Oleh karena itu program pemuliaan tanaman perlu dilakukan untuk meningkatkan protein kacang tunggak.

Sumber daya genetik tanaman kacang tunggak merupakan bahan dasar penting pada program perbaikan tanaman. Sumber daya genetik perlu memiliki keragaman yang luas untuk mendukung program pemuliaan tanaman (Trustinah et al., 2017). Kacang tunggak merupakan tanaman menyerbuk sendiri, genotipe yang terbentuk homozigot dimana keragaman genetiknya tidak seberagam tanaman menyerbuk silang, sehingga perlu dilakukan upaya untuk meningkatkan keragaman. Mutasi buatan dapat dipakai untuk meningkatkan keragaman genetik dalam pembentukan varietas unggul baru. Sinar gamma merupakan mutagen yang paling banyak digunakan dalam pembentukan varietas mutan (Human, 2003). Sinar gamma merupakan radiasi pengion yang mempunyai daya tembus tinggi
(Poespodarsono, 1986) juga mempunyai kemampuan penetrasi cukup kuat kedalam jaringan tanaman (Herawati dan Setiamiharja, 2000). Mutasi dapat menyebabkan perubahan sifat-sifat genetik yang dapat diwariskan (Mba, 2013).

Mutasi dilakukan untuk memperbesar variasi suatu tanaman yang dimutasi sehingga dapat dipilih sifat atau karakter tanaman yang dikehendaki, misalnya variasi kandungan gizi atau morfologi dan penampilan tanaman (Amien dan Carsono, 2008). Penelitian induksi mutasi iradiasi sinar gamma pada tanaman kacang tunggak diharapkan dapat memunculkan genotipe baru yang potensial yang dapat dimanfatkan untuk perakitan varietas unggul baru kacang tunggak.

\section{METODE PENELITIAN}

Penelitian dilaksanakan di Kebun Percobaan Pusat Kajian Hortikultura Tropika (PKHT) Institut Pertanian Bogor jalan kebun percobaan Pasir Kuda yang berada pada ketinggian $250 \mathrm{~m}$ dpl. Induksi mutasi iradiasi sinar gamma kacang tunggak dilaksanakan di Pusat Aplikasi Teknologi Isotop dan Radiasi (PATIR) Badan Tenaga Nuklir Naional (BATAN) Pasar Jumat Jakarta Selatan pada bulan Oktober 2017.

Penelitian dilaksanakan dengan meradiasi benih kacang tunggak genotipe KM-4 menggunakan iradiator Gamma Chamber 4000A dengan dosis 0, 200, 400, 600 dan 800 Gy di PATIR BATAN. Masing-masing dosis terdiri dari 100 benih sehingga total terdapat 500 benih. Benih yang sudah diradiasi kemudian ditanam menggunakan polybag $60 \mathrm{~cm} \mathrm{x}$ $60 \mathrm{~cm}$ dengan jarak tanam $5 \mathrm{~cm} \times 5 \mathrm{~cm}$. Penentuan dosis $\mathrm{LD}_{50}$ dilakukan menggunakan metode Best Curve Fit Analyze dengan menghitung jumlah rasio tanaman yang hidup terhadap total tanaman pada saat tanaman berumur 2 minggu setelah tanam (mst) kemudian 
dinanalisis mengunakan software Curve Expert.

Penelitian dilaksanakan di kebun PKHT Pasir kuda dan PATIR BATAN. Penelitian dilaksanakan pada bulan November 2017 - Februari 2018. Penelitian dilaksanakan dengan meradiasi benih kacang tunggak dengan dosis $0, \mathrm{LD}_{50-100}, \mathrm{LD}_{50-50}, \mathrm{LD}_{50}, \mathrm{LD}_{50+50}$ dan $\mathrm{LD}_{50+100}$ Gy. Penelitian dilaksanakan menggunakan Rancangan Kelompok Lengkap Teracak (RKLT). Setiap perlakuan diulang empat kali. Setiap ulangan terdiri dari 50 tanaman, sehingga total terdapat 1200 tanaman percobaan.

Menurut Mattjik dan Sumertajaya (2013) model matematik yang digunakan adalah:

$$
Y i j=\mu+\tau i+\beta j+\varepsilon i j
$$

Keterangan:

$$
\begin{aligned}
& \text { Yij } \quad= \begin{array}{l}
\text { Respon tanaman } \\
\text { terhadap dosis iradiasi } \\
\text { ke-i dan ulangan ke- } \mathrm{j}
\end{array} \\
& \mu \quad= \text { Nilai tengah populasi } \\
& \tau \mathrm{i} \quad= \begin{array}{l}
\text { Pengaruh iradiasi ke-i } \\
(\mathrm{i}=1,2,3,4,5)
\end{array} \\
& \beta \mathrm{j} \quad= \begin{array}{l}
\text { Pengaruh ulangan ke-j } \\
(\mathrm{j}=1,2,3,4)
\end{array} \\
& \mathrm{eij} \quad=\quad \begin{array}{l}
\text { Pengaruh galat } \\
\text { percobaan genotipe ke- } \\
\text { i dan ulangan ke- } \mathrm{j}
\end{array}
\end{aligned}
$$

Benih hasil radiasi ditanam langsung di kebun percobaan dengan jarak tanam $50 \mathrm{~cm}$ x $50 \mathrm{~cm}$ pada bedengan berukuran $100 \mathrm{~cm} \times 1250 \mathrm{~cm}$ dengan jarak antar bedengan $50 \mathrm{~cm}$ dengan menanam 1 benih tiap lubang tanam. Pemupukan dilakukan menggunakan pupuk $\mathrm{N}$ 20 kg.ha- ${ }^{-1}$, P 40 kg.ha- ${ }^{-1}$ dan K 40 kg.ha ${ }^{-1}$ (Adiarwanto et al., 1998). Penyiraman, pengendalian gulma dan hama penyakit tanaman dilakukan menyesuaikan keadaan tanaman dilapang. Pemasangan ajir dilakukan saat tanaman berumur 2 minggu setelah tanam. Panen dilakukan pada saat polong $80-90 \%$ telah kering (Adiarwanto et al., 1998).

Peubah yang diamati pada penelitian ini adalah tinggi tanaman, lebar tajuk, panjang tangkai, panjang daun, dan lebar daun diukur pada saat tanaman berbunga. Periode panen, panjang polong, jumlah biji per polong dan berat biji per tanaman Kandungan protein biji, dianalisis pada biji hasil penggabugan setiap dosis iradiasi pada masing-masing ulangan. Analisis dilakukan di Laboratorium Pengujian Departemen Agronomi dan Hortikultura IPB. Analisis kandungan protein biji dilakukan dengan menggunakan metode Kjeldahl menurut AOAC (2001) dengan perhitungan \% N dan $\%$ protein sebagai berikut :

$\% \mathrm{~N}=\mathrm{mL} \mathrm{HCl}$ sampel $-\mathrm{mL} \mathrm{HCl}$ blanko x M HCl x 14,01 / g sampel x 10

$\%$ Protein kasar $=\% \mathrm{~N}$ x faktor konversi $(6,25)$

Data yang diperoleh kemudian dianalisis ragam dan bila berpengaruh nyata maka dilakukan uji lanjut DMRT pada taraf 5\% menggunkan software SAS.

\section{HASIL DAN PEMBAHASAN}

\section{Persentase Hidup dan Radiosensitivitas}

Pada karakter persentase hidup dapat dilihat bahwa benih yang diradiasi mempunyai daya hidup yang lebih rendah dibanding dengan yang tidak diradiasi. Hal ini diduga karena perkembangan benih yang tidak sempurna akibat mutasi sehingga viabilitas benih meurun. Keadaan demikian sama dengan perlakuan iradiasi pada buncis (Hameed et al., 2008), chickpea (Shah et al., 2010), kedelai (Hanafiah et al., 2010), kacang panjang (Kon et al., 2007) dan kacang merah (Marwiyah et al., 2017). Tabel 1 menunjukkan penurunan persentase hidup tanaman kacang tunggak berbanding lurus dengan peningkatan dosis iradiasi sinar gamma. Ulukapik et al. (2015) menyatakan bahwa pemberian dosis iradiasi sinar gamma dapat menyebabkan menurunnya persentase 
perkecambahan dan tingkat kelangsungan hidup tanaman yang kemungkinan diakibatkan oleh perbedaan keberadaan sintesis DNA dan metabolisme biji.

Tabel 1. Persentase Hidup Tanaman Kacang Tunggak pada Umur 2 MST

\begin{tabular}{cc}
\hline $\begin{array}{c}\text { Dosis } \\
(\mathrm{Gy})\end{array}$ & $\begin{array}{c}\text { Persentase Hidup } \\
(\%)\end{array}$ \\
\hline 0 & 88 \\
200 & 84 \\
400 & 78 \\
600 & 62 \\
800 & 44 \\
\hline
\end{tabular}

Perubahan yang diakibatkan oleh iradiasi sinar gamma dapat dilihat dari tingkat sensitivitas tanaman. Uji radiosensitivitas dilakukan untuk memperoleh nilai $\mathrm{LD}_{50}$. Hasil analisis curve fit pada tanaman kacang tunggak genotipe KM4 menunjukkan bahwa model terbaik untuk mewakili presentase hidup adalah Polynomial Regression dengan persamaan $\mathrm{Y}=88-0,048333 \mathrm{x}+$ $0,000258 \times 2-0,000001 \times 3$. Berdasarkan persamaan tersebut dapat diperoleh nilai $\mathrm{LD}_{50}$ sebesar 724,84 Gy (Gambar 1).

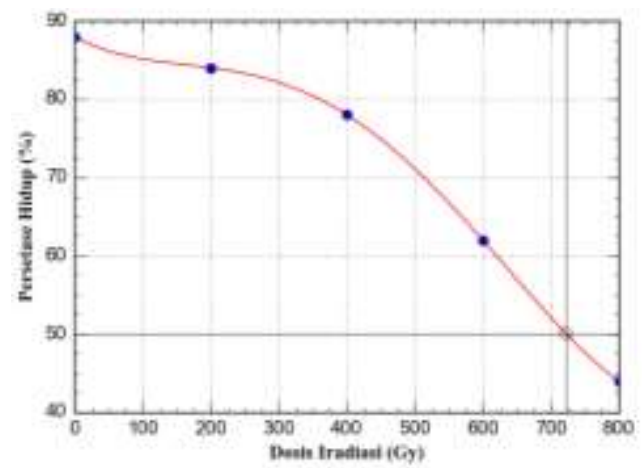

Gambar 1. Pengaruh dosis iradiasi sinar gamma terhadap presentase hidup kacang tunggak genotipe KM4

\section{Karakter Vegetatif Tanaman}

Pengaruh iradiasi sinar gamma terhadap kacang tunggak dapat dilihat pada fase vegetatif meliputi tinggi tanaman, lebar tajuk, panjang tangkai, panjang daun dan lebar daun. Hasil analisis ragam menunjukkan bahwa dosis iradiasi yang diberikan berpengaruh nyata terhadap tinggi tanaman, lebar tajuk, panjang tangkai dan panjang daun tetapi tidak berpengaruh nyata terhadap lebar daun. Tinggi tanaman kacang tunggak yang diradiasi berbeda nyata lebih rendah dengan tanaman yang tidak diradiasi (0 Gy), dimana semakin tinggi dosis iradiasi berbanding lururs dengan penurunan tinggi tanaman (Tabel 2). Perubahan yang sama terjadi pada tanaman kedelai yang mengalami penurunan tinggi tanaman ketika mendapat perlakuan iradiasi dengan dosis yang semakin tinggi (Hanafiah et al., 2010). Sutapa dan Kasmawan (2016) menyatakan bahwa semakin tinggi dosis iradiasi yang diberikan maka pertumbuhan tanaman semakin terganggu. Indrayanti et al. (2012) menunjukkan bahwa semakin tinggi dosis iradiasi, tanaman menjadi lebih pendek dan berbeda nyata dengan kontrol.

Pengaruh dosis iradiasi terhadap lebar tajuk berbeda nyata lebih lebar terhadap tanaman 0 Gy. Tabel 2 menunjukkan bahwa tanaman 0 Gy mempunyai ratarata tajuk paling sempit dibandingkan dengan tanaman $0 \mathrm{~Gy}$. Keragaman tinggi tanaman dan lebar tajuk pada tanaman yang diradiasi cenderung lebih tinggi dibanding dengan tanaman 0 Gy. Keragaman tertinggi diperoleh pada dosisi 750 Gy. Hal ini menunjukkan bahwa iradiasi sinar gamma dapat meningkatkan keragaman pada kacang tunggak.

Hasil analisis pada Tabel 3 menunjukkan bahwa karakter panjang tangkai, panjang daun dan lebar daun rata-rata tertinggi diperoleh pada tanaman 0 Gy meskipuntidak berbeda nyata dengan dosis650 Gy dan $700 \mathrm{~Gy}$. Dosis iradiasi mengakibatkan pertumbuhan daun menjadi terhambat dibandingkan dosis 0 Gy. Dosis iradiasi yang diberikan mengakibatkan terjadi keragaman daun jika dibandingkan 
dengan dosis $0 \quad$ Gy. Menurut Sigurbjornsson (1983) iradiasi dapat menyebakan pembelahan sel menjadi terhambat yang selanjutnya dapat menghambat proses pembentukan organ. Hal tersebut dapat terjadi karena adanya kerusakan pada sel meristem pada tanaman.

Tabel 2. Pengaruh dosis iradiasi sinar gamma terhadap tinggi tanaman dan lebar tajuk kacang tunggak

\begin{tabular}{cccccc}
\hline Peubah & Dosis (Gy) & Minimal & Maksimal & Rerata & KK $(\%)$ \\
\hline & 0 & 37,2 & 136,0 & $93,87 \mathrm{a}$ & 22,23 \\
Tinggi Tanaman & 650 & 21,3 & 109,2 & $73,03 \mathrm{~b}$ & 30,78 \\
(cm) & 700 & 22,9 & 113,0 & $67,23 \mathrm{bc}$ & 33,76 \\
& 750 & 10,2 & 130,3 & $65,10 \mathrm{bc}$ & 48,15 \\
& 800 & 30,0 & 107,0 & $62,83 \mathrm{c}$ & 38,27 \\
& 850 & 24,1 & 108,1 & $58,22 \mathrm{c}$ & 37,12 \\
\hline \multirow{2}{*}{ Lebar Tajuk } & 0 & 33,0 & 101,0 & $68,09 \mathrm{~b}$ & 20,07 \\
(cm) & 650 & 31,1 & 132,0 & $77,23 \mathrm{a}$ & 25,96 \\
& 700 & 37,0 & 123,1 & $81,09 \mathrm{a}$ & 23,09 \\
& 750 & 20,2 & 133,2 & $83,44 \mathrm{a}$ & 28,53 \\
& 800 & 36,9 & 137,0 & $85,24 \mathrm{a}$ & 27,11 \\
& 850 & 50,0 & 128,0 & $81,94 \mathrm{a}$ & 24,45 \\
\hline
\end{tabular}

Keterangan: Nilai yang diikuti huruf yang sama pada kolom rerata pada setiap peubah tidak berbeda nyata berdasarkan uji DMRT pada taraf 5\%

Tabel 3. Pengaruh dosis iradiasi sinar gamma terhadap panjang tangkai, panjang daun dan lebar daun kacang tunggak

\begin{tabular}{cccccc}
\hline Peubah & Dosis (Gy) & Minimal & Maksimal & Rerata & KK $(\%)$ \\
\hline & 0 & 3 & 16 & $11,71 \mathrm{a}$ & 10,43 \\
Panjang Tangkai & 650 & 3 & 16 & $11,65 \mathrm{a}$ & 18,19 \\
(cm) & 700 & 5 & 16 & $11,11 \mathrm{ab}$ & 16,01 \\
& 750 & 3 & 14 & $10,81 \mathrm{~b}$ & 18,65 \\
& 800 & 7 & 15 & $10,65 \mathrm{~b}$ & 16,88 \\
& 850 & 8 & 13 & $10,66 \mathrm{~b}$ & 13,29 \\
\hline & 0 & 7,9 & 14,0 & $11,45 \mathrm{a}$ & 10,85 \\
Panjang Daun & 650 & 3,9 & 14,5 & $11,20 \mathrm{ab}$ & 15,54 \\
(cm) & 700 & 3,0 & 14,0 & $10,78 \mathrm{ab}$ & 17,85 \\
& 750 & 1,7 & 14,0 & $10,51 \mathrm{ab}$ & 22,93 \\
& 800 & 6,5 & 14,0 & $10,76 \mathrm{ab}$ & 13,91 \\
& 850 & 8,0 & 14,0 & $10,84 \mathrm{ab}$ & 11,68 \\
\hline Lebar Daun & 0 & 5,9 & 10,0 & $8,07 \mathrm{~b}$ & 11,20 \\
(cm) & 650 & 3,0 & 10,5 & $7,67 \mathrm{~b}$ & 13,96 \\
& 700 & 2,0 & 11,5 & $7,41 \mathrm{~b}$ & 23,22 \\
& 750 & 2,5 & 10,2 & $6,87 \mathrm{~b}$ & 26,54 \\
& 800 & 3,0 & 10,0 & $7,22 \mathrm{~b}$ & 17,79 \\
& 850 & 4,5 & 9,3 & $9,70 \mathrm{a}$ & 14,00 \\
\hline
\end{tabular}

Keterangan: Nilai yang diikuti huruf yang sama pada kolom rerata pada setiap peubah tidak berbeda nyata berdasarkan uji DMRT pada taraf 5\% 


\section{Karakter Generatif Tanaman}

Pada fase generatif pengaruh dosis iradiasi dapat dilihat pada peubah periode panen, panjang polong, jumlah biji/polong, berat biji per tanaman dan protein biji. Hasil analisis ragam menunjukkan bahwa dosis iradiasi berpengaruh sangat nyata terhadap periode panen, panjang polong, jumlah biji per polong, berat bij per tanaman dan kandungan protein biji jacang tunggak.

Periode panen kacang tunggak dapat dilihat pada Tabel 4 bahwa keragaman tanaman yang diraidiasi lebih tinggi dibanding tanaman 0 Gy. Keragaman periode panen tertinggi diperoleh pada dosisi $750 \mathrm{~Gy}$. Hal ini menunjukkan bahwa iradiasi dapat meningkatkan keragaman. Periode panen tanaman berkaitan erat dengan pembungaan dan pemasakan buah. Terdapat banyak faktor yang mempengaruhi pembungaan suatu tanaman baik internal maupun eksternal (Nurtjahjaningsih et al., 2012). Menurut Dhakhanamoorthy et al. (2010) kejadian awalnya pembungaan dan pemasakan buah diakibatkan karena adanya perubahan fisiologi pada tanaman oleh suatu mutagen.

Tabel 4. Pengaruh dosis iradiasi sinar gamma terhadap periode panen (hari) kacang tunggak

\begin{tabular}{ccccc}
\hline Dosis (Gy) & Minimal & Maksimal & Rerata & KK $(\%)$ \\
\hline 0 & 14 & 39 & $19,23 \mathrm{a}$ & 32,63 \\
650 & 7 & 39 & $13,23 \mathrm{c}$ & 56,16 \\
700 & 7 & 39 & $18,12 \mathrm{ab}$ & 54,11 \\
750 & 7 & 36 & $15,44 \mathrm{bc}$ & 58,14 \\
800 & 7 & 32 & $14,91 \mathrm{c}$ & 43,29 \\
850 & 7 & 36 & $19,78 \mathrm{a}$ & 45,43 \\
\hline
\end{tabular}

Keterangan: Nilai yang diikuti huruf yang sama pada kolom rerata pada setiap peubah tidak berbeda nyata berdasarkan uji DMRT pada taraf 5\%

Nilai rerata tertinggi pada peubah panjang polong diperoleh pada dosis 700 Gy yaitu $19,06 \mathrm{~g}$ sedangkan yang terendah pada dosis 650 Gy yaitu 13,73 g. Pada peubah jumlah biji per polong dan berat biji per tanaman tertinggi diperoleh pada tanaman dengan dosis iradiasi 850 Gy tetapi tidak berbeda nyata dengan dosis $0 \mathrm{~Gy}$. Tanaman yang diradiasi menunjukkan keragaman yang lebih tingi dibanding tanaman 0 Gy dan nilai keragaman tertinggi diperoleh pada tanaman dengan dosis 750 Gy yang merupakan dosis paling mendekati $\mathrm{LD}_{50}$.

Tabel 6 menunjukkan bahwa tanaman dosis 0 Gy memperoleh kandungan protein $25,24 \%$ tetapi tidak berbeda nyata dengan tanaman pada dosis 750 Gy yaitu $25,25 \%$. Kandungan protein tertinggi diperoleh pada dosus 700 Gy yaitu $27,25 \%$ tetapi tidak berbeda nyata dengan tanaman pada dosis 850 Gy dan
650 Gy. Peningkatan kandungan protein pada biji tanaman hasil iradiasi diduga karena adanya perubahan metabolisme tertentu yang menyebabkan cadangan protein pada biji meningkat.

Berdasarkan data yang dianalisis pada fase vegetatif dan generatif (Tabel 2, 3, 4 dan 5) menunjukkan bahwa perlakuan dosisi iradiasi sinar gamma yang diberikan dapat meningkatkan keragaman fenotip kacang tunggak. Iradiasi sinar gamma dapat meningkatkan keragaman karena pengaruh radiasi dapat menimbulkan perubahan struktur gen, struktur kromosom, ataupun jumlah kromosom, sehingga dapat diperoleh genotipe dengan variasi baru (Maharani et al., 2015). 
Tabel 5. Pengaruh dosis iradiasi sinar gamma terhadap panjang polong, jumlah biji/polong dan berat biji/tanaman kacang tunggak

\begin{tabular}{cccccc}
\hline Peubah & Dosisi (Gy) & Minimal & Maksimal & Rerata & KK (\%) \\
\hline & 0 & 9,60 & 18,80 & $16,42 \mathrm{~b}$ & 10,86 \\
Panjang Polong & 650 & 8,00 & 21,33 & $13,73 \mathrm{c}$ & 15,97 \\
(cm) & 700 & 6,00 & 23,00 & $19,06 \mathrm{a}$ & 17,43 \\
& 750 & 7,50 & 19,00 & $14,18 \mathrm{c}$ & 17,73 \\
& 800 & 13,50 & 19,50 & $16,41 \mathrm{~b}$ & 11,42 \\
& 850 & 11,00 & 20,50 & $16,04 \mathrm{~b}$ & 15,11 \\
\hline & 0 & 7,20 & 11,50 & $10,05 \mathrm{a}$ & 10,85 \\
Jumlah Biji per & 650 & 5,00 & 14,50 & $8,38 \mathrm{~b}$ & 19,78 \\
Polong & 700 & 5,00 & 14,60 & $9,83 \mathrm{a}$ & 22,38 \\
& 750 & 5,71 & 17,00 & $9,87 \mathrm{a}$ & 30,41 \\
& 800 & 6,67 & 14,00 & $9,89 \mathrm{a}$ & 20,27 \\
& 850 & 6,00 & 14,71 & $10,31 \mathrm{a}$ & 25,84 \\
\hline Berat biji per tanaman & 0 & 1,47 & 17,42 & $12,54 \mathrm{abc}$ & 45,89 \\
(g) & 650 & 0,70 & 24,00 & $5,91 \mathrm{~d}$ & 66,22 \\
& 700 & 1,00 & 20,00 & $16,05 \mathrm{a}$ & 56,00 \\
& 800 & 1,00 & 20,00 & $11,60 \mathrm{bc}$ & 68,92 \\
& 850 & 0,67 & 22,00 & $15,11 \mathrm{ab}$ & 56,57 \\
\hline
\end{tabular}

Keterangan: Nilai yang diikuti huruf yang sama pada kolom rerata pada setiap peubah tidak berbeda nyata berdasarkan uji DMRT pada taraf 5\%

Tabel 6. Pengaruh dosis iradiasi sinar gamma terhadap protein (\%) biji kacang tunggak

\begin{tabular}{ccccc}
\hline Dosis $(\mathrm{Gy})$ & Minimal & Maksimal & Rerata & KK $(\%)$ \\
\hline 0 & 24,27 & 25,87 & $25,24 \mathrm{c}$ & 2,80 \\
650 & 26,55 & 27,29 & $26,95 \mathrm{a}$ & 1,13 \\
700 & 26,55 & 27,69 & $27,25 \mathrm{a}$ & 1,80 \\
750 & 24,95 & 25,64 & $25,25 \mathrm{c}$ & 1,30 \\
800 & 25,98 & 26,55 & $26,21 \mathrm{~b}$ & 0,94 \\
850 & 26,95 & 27,47 & $27,21 \mathrm{a}$ & 0,79 \\
\hline
\end{tabular}

Keterangan: Nilai yang diikuti huruf yang sama pada kolom rerata tidak berbeda nyata berdasarkan uji DMRT pada taraf 5\%

Keragaman tertinggi diperoleh pada dosis $750 \mathrm{~Gy}$ yang merupakan dosis yang berkisar pada $\mathrm{LD}_{50}$. Berdasarkan nilai $\mathrm{LD}_{50}$ diperoleh dosis iradiasi yang dapat digunakan untuk menginduksi keragaman pada tanaman dengan karakter yang diinginkan. Menurut Sudrajat dan Zanzibar (2009) iradiasi yang dilakukan pada kisaran $\mathrm{LD}_{50}$ dengan pertimbangan bahwa kerusakan fisiologis berimbang dengan perubahan genetik yang diperoleh. Albokari et al., (2012) menyatakan bahwa dosis optimum dapat menghasilkan variasi terbanyak dengan minimal mutan yang tidak diinginkan, yang biasa terjadi di sekitar $\mathrm{LD}_{50}$.

Pada kandungan protein biji menunjukkan bahwa perlakuan dosis iradiasi tidak meningkatkan keragaman dimana diperoleh keragaman dosisi 0 Gy paling tinggi dibanding tanaman yang diradiasi. Hal ini tidak sejalan dengan teori bahwa iradiasi dapat meningkatkan keragaman. Hai inidapat terjadi karena mutasi bersifat acak sehingga hasilnya tidak dapat diprediksi. Menurut 
Handayani (2006) berbagai faktor dapat mempengaruhi keberhasilan penggunaan radiasi pada tanaman, antara lain genotipe, bagian tanaman yang digunakan, stadia perkembangan sel tanaman, jumlah kromosom, umur jaringan, oksigen, temperatur, dosis radiasi dan ada kemungkinan beberapa pengaruh faktor lain seperti ketahanan atau kekebalan tanaman itu sendiri terhadap pemberian sinar gamma sehingga radiasi tidak dapat merusak gen pengendali produksi protein pada kacang tunggak.

\section{SIMPULAN}

Nilai $\mathrm{LD}_{50}$ tanaman kacang tunggak adalah 724,84 Gy. Iradiasi sinar gamma pada dosis 750 Gy menghasilkan keragaman tertinggi. Iradiasi sinar gamma tidak meningkatkan keragaman terhadap kandungan protein biji kacang tunggak.

\section{DAFTAR PUSTAKA}

Adiarwanto, T., Riwanodja dan Suhartina. 1998. Budi daya tanaman kacang tunggak. Monograf BALITKABI 3: 78-83.

Albokari, M.M.A., S.M. Alzahrani, A.S. Alsalman 2012. Radiosensitivity of some cultivars of wheat (Triticum aestivum L.) to gamma irradiation. Bangladesh J. Bot. 41(1):1-5.

Amien, S. dan N., Carsono. 2008. Teknologi Nuklir Guna Merakit Kultivar Unggul. http://www.pikiranrakyat.com [Oktober 2018].

[AOAC] Association of Official Analytical Chemist. 2001. Protein (Crude) in Animal Feed, Forage (Plant Tissue), Grain, and Oilseed. Journal AOAC International.

[BKPPP] Badan Ketahanan Pangan dan Pelaksana Penyuluhan. 2014. Data Kandungan Gizi Bahan Pangan dan Olahan Golongan Kacang-kacangan dan Biji-bijian. Yogyakarta (ID): BKPPP Bantul.
Dhakhanamoorthy D., R. Selvaraj and A. Chidambaram. 2010. Physical and chemical mutagenesis in Jatropha curcas L. to induced variabiity in seed germination, growth and yield traits. Journal of Plant Biology. 55:(2):113125.

Handayani, W. 2006. Keragaman genetik mawar mini dengan irradiasi sinar gamma. Warta Penelitian dan Pengembangan Pertanian 28 (4) : 17 18.

Hanafiah D.S., Trikoesoemaningtyas, S. Yahya dan D. Wirnas. 2010. Studi radiosensisitivitas kedelai (Glycine max [L] Merr.) varietas Agromulyo melalui iradiasi sinar gamma. Jurnal Ilmu-ilmu Hayati dan Fisik 12:105111.

Hameed A., T.M. Shah, B.M. Atta, M.A. Haq, H. Sayed.2008. Gamma irradiation effects on seed germination and growth, protein content, peroxidase and protease activity, lipid peroxidation in Desi and Kabuli Chickpea. Pak. J. Bot. 40:1033-1041.

Herawati, T dan Setiamihardja, R. 2000. Pemuliaan Tanaman Lanjutan. Universitas Padjajaran. Bandung.

Human, S. 2003. Peran iptek nuklir dalam pemuliaan tanaman untuk mendukung industri pertanian. Prosiding Pertemuan dan Presentasi Ilmiah Penelitian Dasar Ilmu Pengetahuan dan Teknologi Nuklir P3TM BATAN. Yogyakarta.

Indrayanti, R., N.A. Mattjik, A. Setiawan, Sudarsono. 2012. Evaluasi keragaman fenotipik pisang cv. Ampyang hasil iradiasi sinar gamma di rumah kaca. J. Hort. Indonesia 3(1): 24-34.

Kon, E., O.H. Ahmed, S. Saamin. 2007. Gamma radiosensitivity on long bean (Vigna sesquipedalis). Am. J. Appl. Sci. 4:1090-1093.

Mattjik AA. dan Sumertajaya. 2013. Perancangan Percobaan. dengan Aplikasi SAS dan Minitab. Bogor (ID): IPB Press.

Maharani S., N.Khumaida, M Syukur dan S. W. Ardie.2015. 
Radiosensitivitas dan keragaman ubi kayu (Manihot esculenta Crantz) hasil iradiasi sinar gamma. J. Agron. Indonesia 43 (2): 111-117.

Marwiyah S., H. Purnamawati, P.I. Sembiring. 2017. Induksi mutasi fisik dengan iradiasi sinar gamma pada kacang merah. Comm. Hort. J. 1(1):49-55.

Mba, C. 2013. Induced mutations unleash the potential of plant genetic resources for food and agriculture. Agronomy 3(1): 200.231.

Nurtjahjaningsih, I.L.G., A.Y.P.B.C. Widyatmoko, P. Sulistyawati, A. Rimbawanto. 2012. Screening penanda mikrosatelit Shorea curtisii terhadap jenis-jenis Shorea penghasil tengkawang. J. Pemuliaan Tanaman Hutan 6:49-56.

Poespodarsono, S. 1986. Dasar-dasar Ilmu Pemuliaan Tanaman. Institut Pertanian Bogor. Bogor.

Shah, T.M., J.I. Mirza, M.A. Haq, B.M. Atta. 2008. Radiosensitivity of various chickpea genotipes in MI generation. Pak. J. Bot. 40:649-665.

Sigurbjornsson, B. 1983. Induce mutations, p. 153- 176. In D. R. Wood, K. M. Rawal and M. N. Wood (Eds.). Crop Breeding. The American Society of Agronomy, Inc. and The Crop Science Society of America, Inc. Wisconsin.
Sudrajat, D. J., dan M. Zanibar. 2009. Prospek teknologi iradiasi sinar gamma dalam peningkatan mutu benih tanaman hutan. Info Benih. 13:158-163.

Sutapa, G.N. dan Kasmawan, I.G.A. 2016. Efek induksi mutasi radiasi gamma 60Co pada pertumbuhan fisiologis tanaman tomat (Lycopersicon esculentum L.). J. Kes. Rad and Ling. 1:5-11.

Syarifah, H. 2002. Pembuatan biskuit dari tepung kacang tunggak (Vigna unguiculata $\mathrm{L}$. walp) dan tepung fine bran (kajian proporsi tepung dan soda kue terhadap mutu biskuit). Fakultas Teknologi Pertanian. Universitas Brawijaya. Malang.

Trustinah, A. Kasno, Wijanarko, H. Kuswantoro, R. Iswanto R. 2008. Tanggap genotipe kacang-kacangan di lahan kering masam. Prosiding Seminar Hasil Penelitian Kacangkacangan dan Umbi-umbian. Puslitbangtan. Bogor.

Trustinah, A. Kasno, MJ. Mejaya. 2017. Keragaman sumber daya genetik kacang tunggak. Penelitian Pertanian Tanaman Pangan 1(2): 165-172.

Ulukapik, Nasircilar AG. 2015. Developments of gamma ray application on mutation breeding studies in recent years. Int Confon Adv in Agr, Biol and Env Sci. London 22-23 July 2015. 